\title{
TV/Series
}

1 | 2012

Les Séries télévisées américaines contemporaines :

entre la fiction, les faits, et le réel

\section{The Treatment of the Law: Between Reality and Imagination in Television Legal Series}

Barbara Villez

\section{(2) OpenEdition \\ Journals}

Electronic version

URL: http://journals.openedition.org/tvseries/1531

DOI: $10.4000 /$ tvseries.1531

ISSN: 2266-0909

Publisher

GRIC - Groupe de recherche Identités et Cultures

Electronic reference

Barbara Villez, « The Treatment of the Law: Between Reality and Imagination in Television Legal Series », TV/Series [Online], 1 | 2012, Online since 15 May 2012, connection on 01 May 2019. URL : http:// journals.openedition.org/tvseries/1531; DOI : 10.4000/tvseries.1531

\section{(c) (i) (9)}

TV/Series est mis à disposition selon les termes de la licence Creative Commons Attribution - Pas d'Utilisation Commerciale - Pas de Modification 4.0 International. 
The Treatment of the Law:

Between Reality and Imagination in Television Legal Series.

\author{
Barbara VILLEZ
}

For over sixty years American television series dealing with law and justice have helped the public to construct a legal culture, acquiring criteria on the professions, procedure and their rights as citizens. As the series became more complex, the details pertaining to courtroom set up and what lawyers could or could not do became increasingly precise. Yet, many elements were played with, reality stretched in order to engender curiosity, open eyes and ears and get people to think.

$\mathrm{L}$ egal series are based on conflict and therefore make good stories. They encourage active viewership because each side of the dispute gets equal time, or nearly, to present its generally reasonable arguments. This is a realistic representation of the law, because courts deal with conflict and each party usually thinks it has a legitimate cause to defend. The conflicts at the heart of the stories are pertinent because they reflect the current concerns of television viewers: stories of crime, of betrayal, fraud, corruption, terrorism, personal injury and the eternal family trouble. Courtroom scenes are constructed on well-written opposing arguments. Viewers are doubly implicated at these moments: evaluating the arguments while waiting for the jury decision in favor of one of the two parties. If a viewer has never had direct experience with legal conflict, or even indirect for that matter, the shows give him a notion of the role of law and justice in the lives of ordinary citizens.

Over time, loyal viewing has taught audiences a lot about the legal system and their individual rights. Consequently, today, these series have captured jurists' interest in them as sources of public knowledge of the law ${ }^{1}$. Today as more scholars are looking at the representation of the law in film and television series, the question of reality and fiction has come into debate. Some of the questions concern the obligation of realistic portrayals, and if so, with regard to what aspects?

${ }^{1}$ See "Television Practices and the Construction of a Legal Culture in five European countries and in the United States", Project of the research group JILC (Justices, Images, Languages, Cultures), financed by the MSH Paris Nord, indicates that people recognize television fictions as a major source of their legal knowledge which in many of the countries of the study, was better than expected. The results of the study appear in forthcoming articles. 
Some jurists feel that people take this entertainment content too much for truth. They feel that scriptwriters take too much license in depicting the legal professions and courtroom procedure ${ }^{2}$ and thus denigrate and dilute the representation of the judicial system 3 . Others are more easily satisfied with a realistic, although erroneous, "effect", bowing to public expectations in some cases ${ }^{4}$. Series structure expectations. Examples of this abound: juries today are uncomfortable when no DNA evidence is presented at trial; the French demand their Miranda warnings or a phone call when arrested, although these rights do not exist in the French context; French lawyers have started moving around the courtroom, approaching witnesses, whereas in reality they are confined to a specific space and must operate from behind their bench. On the other hand, jurors do need some bases to deal with the responsibilities set upon them. Lévy-Bruhl suggested that jurors can more easily conceive of the acts they must judge, if they can recognize these from experience 5 . Fictions bring viewers important virtual experience. For Nussbaum, fiction sensitizes judges and legislators to the plights of those who will come before them in court ${ }^{6}$. This obviously works for jurors as well. Justice Cardozo stressed the contribution of literature to judicial training: "We are not to close our eyes as judges to what we must perceive as men7." Such empathy is an essential factor of democracy.

The law suffers from the idea that it is only serious and rigid, rather than a creative process. This attitude would require legal series to represent reality; one does not play around with such subjects. However, a good number of courtroom series have been comedies, or rather "dramedies" 8 ", justifiably using both drama and comedy to portray human conflict and resolution. Comedy and surprise push viewers to take notice and listen more actively. The results are more efficient than reproducing repetitive scenes that people hardly notice any more. It appears, therefore, less vital to ask whether to privilege the real or the imaginary in telling stories, than to question where

\footnotetext{
2 See B.Villez, «Law \& Order UK: Interviews with members of the British Legal Profession" in Critical Studies in Television, dossier, Manchester, University of Manchester Press, $n^{\circ}$ 6/1, spring 2011, p. 89-98.

3 See R. Sherwin, When Law Goes Pop, Chicago, University of Chicago Press, 2000.

${ }^{4}$ Reference is often made to Barthes's « effet de réel », but putting jurors in a box in the courtroom of a French film raises the question of how far liberties should be taken and with respect to what aspects. Jurors in the French courts are not seated on their own, as they do not decide on their own. Jurors are either absent (tribunal correctionnel) or, in the Cour d'Assises for serious crimes, they are placed on either side of the three judges at the bench in front of the court.

${ }^{5}$ H. Lévy-Bruhl, La Preuve judiciaire, Paris Marcel Rivière et cie, 1964, p. 46.

${ }^{6}$ See M. Nussbaum, Poetic Justice, Boston, Beason Press, 1995.

7 Justice B. Cardozo, People ex rel Alpha Portland Cement Co v Knapp, $230 \mathrm{NY}$ 48, 63 (1920).

${ }^{8}$ An example of such as series is Ally McBeal, Fox 1997-2004. See B. Villez, Television and the Legal System, London, Routledge, 2009, p. 11-12.
} 
stretching reality is acceptable and to determine for which purpose this should be done.

\section{The place reality and imagination have held over the history of legal series}

For over sixty years American television procedurals, as they are often called, have helped the public to construct a legal culture acquiring knowledge of the professions, procedure and citizens' rights9. There have been nearly 130 legal series during this period with a clear explosion in the years since 2000 (over forty series since the year 2000 with 7 between 2010 and 2011). These series are a source of basic legal education, but they are also myth-makers, facilitating the construction of models and value systems, setting norms and criteria to judge behaviors.

The series began with a very simple narrative structure in the fifties and to satisfy the more sophisticated, more teleliterate ${ }^{10}$ viewers, they have become increasingly complex over the years. Details pertaining to courtroom set up and what lawyers can and cannot do have become quite precise. Writers of procedurals who are often lawyers (nearly all teams are led by or include former lawyers) have addressed viewer expectations bringing difficult legal issues to the public's awareness. Audiences, having acquired a basic mental image of courtroom set-up and activity, became able, in the early 90s, to discover different levels of jurisdiction, weaknesses in the system, pressures on professionals and the unsettling difference between law and justice. Viewers learned legal notions such as judicial accountability, procedural error, jury tampering, constitutional privilege, questions in law going to appeals courts before final judgment in the first instance courts, to name but a few.

The cult Perry Mason ${ }^{11}$ series presented the public with a very limited image of the role of the judge. This role was most often conferred to male actors and he would usually be seen in the background, listening to witnesses answer lawyers' questions. He could rarely, if ever, speak except to overrule or sustain objections from opposing counsel. This helped audiences acquire criteria as to the common law judge's role in court, the role of an arbiter, not the center of activity like the French judge. Audiences noticed that in a common law trial, the lawyers ran the combat. Later series gave viewers insight into more intricate aspects of judicial activity. They saw judges be more directive, biased, or aggressive ${ }^{12}$. Because these behaviors were not lost

9 See definition of a layman's 'legal culture' in Villez, ibid, p. 2.

${ }^{10}$ See D. Bianculli, Teleliteracy, NY, Syracuse University Press, 2000.

${ }^{11}$ CBS, 1957-1966, 1973-1974.

12 Law \& Order (NBC 1997-2011), Ally McBeal (Fox 1997-2002), or Shark (CBS 20062008) for example. 
in narrative detail, they were much more noticeable. In the groundbreaking legal drama Law \& Order ${ }^{13}$, the ripped-from-headline stories were used as inspiration for scenarios which, in the end, no longer resembled the stories of real people. French television representations of the law generally stick to factual details of real headline stories, made into television films (for example the Villemin, Renucci and Domenici cases) consistent with French cultural preferences for cinema and history. However often in French television productions, one finds details of American courtroom setup or procedure absent in reality in French law, but inserted to satisfy the producers' ideas of the public's expectations.

The language used in court has always been a realistic part of the representation of courtroom activity on television. Lawyers repeating "Your Honor" or sentences like "I object, counsel is badgering the witness" became familiar sixty years ago as well as judges' answers "sustaining" or "overruling" objections in court. Again with time, discussions between lawyers and clients allowed the public to eavesdrop on explanations which brought them information on "Y.O.s" (youthful offenders) or "entrapment" (enticement into committing a crime) or "garnishments" (withholdings on a salary at the source in order to pay damages, alimony or fines). Legal terms, elements of legal discourse, interjections, as well as ritual expressions have become familiar to French audiences watching these series in English on DVDs or on late night cable broadcasts. Some of the terms and expressions have been extremely difficult for translators to transpose into French since the two legal systems do not correspond to one another exactly. Consequently, the problem of French citizens addressing their judges in court as "Votre honneur" has irked many a "magistrat", and apparently the annoyance has spread to other European countries of civilest tradition. French judges have expressed concern that the shock of not finding a courtroom corresponding to people's mental image makes the already daunting experience of appearing in court all the more inhibiting. Americans do not have this problem because language, like details of procedure, the seating or order of questioning have all been rendered with great degrees of realism and do correspond to the reality of their system. If procedure becomes a recognizable routine, viewers integrate these details and are free to focus on legal content, on the important issues of a case. Hence the series provide a form of lay legal training.

Time is another element that has been treated with much realism. Despite condensing stories into fifty-minute narratives, television series actually enhance the realistic handling of a legal procedure or a lawyer's career. This is easier than in cinematic

${ }^{13} \mathrm{NBC}, 1990-2011$, the longest running legal drama to date and one of the longest running series of any kind. 
representations because from week to week aspects of procedure can be developed and refined. A glimpse of this is seen in Damages ${ }^{14}$ where much office time is spent preparing and researching a case. We see the lawyers in "discovery" sessions (a preparatory stage where all documents relating to the issue at question can be first identified, found and examined, witnesses questioned before counsel for both parties, etc.; a very time-consuming and thus expensive procedure). The viewer is spared all the boring hours of discovery, but he is used to piecing information together and can imagine much of the process. He does not see all witness interrogations, not all examination-in-chief, or cross-examinations or reexaminations, but by now he knows that this occurs.

The seasons of a successful show allow for the development of careers. Actors age and as they do, so do their characters. When Perry Mason acquired grey hair, a wider waste line and a few more wrinkles, he became a judge and then returned to the university to teach law, leaving the bench or the books once in a while to defend a friend ${ }^{15}$. Bobby Esposito ${ }^{16}$ was disbarred but with time found another mission and became an advisor in a legal aid clinic. Alicia Florrick ${ }^{17}$ who had put her career as a lawyer aside to raise a family, goes to a law firm to start all over as a junior vying with a fresh out of law school competitor for the one opening for a permanent job in the firm.

The late 90s brought to television the David E. Kelley phenomenon. Kelley, a Boston lawyer moved to Hollywood and soon became part of the team of writers for L.A. Law. ${ }^{18}$ This was one of the first series about a big law firm and one of the first as well to deal with civil as well as criminal cases ${ }^{19}$. In the context of the 9os when the public was confronted with failures within the legal system and imperfect lawyers, Kelley was more interested in talking about real issues than in routine legal scenarios. His two series, launched the same year, were contrasting images of the legal profession: one very bleak and one as crazy as the lawsuits brought to the firm ${ }^{20}$. By using less reality in courtroom behaviors, or in client-counsel exchanges, he managed to get the public's attention in order to consider the ethical dilemmas of legal professionals (for example, what is a lawyer's obligation if he knows his client will commit a crime?) or the rampant litigation tendency of the United States (when adolescents sue other

\footnotetext{
${ }^{14}$ Fox, 2007- present.

15 After the end of the Perry Mason series, a number of further episodes were produced, some as made for television movies, bringing the beloved actor and his character in these later periods of the lawyer's career.

${ }^{16} 100$ Centre Street (A\&E, 2001-2002).

${ }_{17}$ The Good Wife (CBS, 2009- present).

${ }^{18}$ NBC, 1986-1994.

${ }_{19}$ This had occurred in the past but on a very infrequent basis. The most important early series to present occasional civil issues was The Defenders, CBS 1961-1965.

${ }^{20}$ The Practice (ABC, 1997-2004) and Ally McBeal (Fox 1997-2002).
} 
adolescents for sexual harassment when one grabs an innocent kiss from the other in the school building). Viewers all know today that lawyers do not yell at judges in court nor do they jump up on tables to prove a point, but without such license it would certainly have been harder for Kelley to get people to sit up and take notice of the real questions he wanted them to take into account. Kelley had already dealt with content questions in another earlier, but less remembered, show, Picket Fences ${ }^{21}$, in which a small-town judge, sheriff and doctor often came together to deal with conflicts between the law and ethics. Cows used as surrogate mothers ${ }^{22}$ was not exactly an example of a realistic legal narrative. However, once the legal battle had led to the decision to destroy the foetuses, it was discovered that several little children in the town, playmates of the characters' children, had been born in this way. The ethical dilemma, between two delicate areas of the law today (medically assisted procreation and abortion) became much less simple In an age of court cases over frozen embryos or cryonics, citizens must not overlook the legal issues involved and television is one of the best ways to bring these questions to them.

\section{The issues are real, the handling is not.}

The most powerful moments in these series have traditionally been when lawyers plead in court. Here the main elements of the dispute are summed up, both sides get to speak and the viewer hears very convincing arguments on each side; the essence of an argument must be grasped at this point. Unlikely courtroom behaviors help here to draw sharper attention to the content of these arguments. Hence, when Alan Shore ${ }^{23}$ pleads before the Supreme Court and suddenly tells Justice Thomas to "please put the magazine down" and listen to him, he gets the viewers to zoom in on the scene. He then scolds the court and reminds the public that the Court has departed from the traditions upon which it was founded, now accepting to hear political questions, protecting government and privileging big business against individual citizens ${ }^{24}$. Cases are named as are monied interests and viewers may be surprised to hear such audacious criticism of the court, but if not in this context where else would it be possible? A newspaper editorial perhaps, but one could wonder whether the impact would be as strong. Shore's antics before the court are, of course, unreal, but the arguments he advances are particularly pertinent because of the political climate at that time. Viewers are pushed to consider the

\footnotetext{
${ }^{21}$ CBS 1992-1996.

22 « Away in the Manger », season 3, episode 10, first aired December 16, 1994.

${ }^{23}$ Boston Legal (ABC, 2004-2008).

24 « The Supreme Court », season 4, episode 17, first aired April 22, 2008.
} 
relation between law and politics, and reminded of the difficult constitutional principle of judicial independence.

The liberties taken in this scene were necessary to produce the desired effect. The rapidity of Shore's jabs at the justices, the comedy and surprise provoked are much more effective than a straightforward speech. Citizens come to the series as viewers seeking entertainment. Once the jurist/writers have their undivided attention, they can force awareness of developments in the law, or the lack of these in light of new situations the courts must deal with. An episode of The Practice gives viewers a chance to discover the freedom common law judges can exercise in the absence of established law. Judge Kittleson, outraged to learn that details of her private life have been revealed on the Internet, presides over a case in which the accused has uploaded intimate images of a young woman on another website ${ }^{25}$. Uploading images is not an offense, the public learns, but having planted a video camera in the girl's bathroom brings the accused to court for theft of her electricity. When Kittleson learns what he has done with these sensitive photographs, she orders him to lower his pants in court and asks him whether he feels embarrassed in front of everyone, whether he feels vulnerable. This obviously unrealistic handling of a case of petty theft involves Internet use and the right to privacy, all currently developing areas of law. There is still much to be done to manage the Internet and to balance user freedom and the protection of individual rights. Here Judge Kittleson basically invents solutions where the law is not yet sufficient. The lack of realism is beside the point, the issues of privacy, freedom of Internet use and the insufficiency of law are very real. Procedure and courtroom decor are respected in this scene, but the public's attention no longer goes to these aspects. The judge sits in front of a bookcase containing volumes of written law. As she transgresses usual judicial behavior and seems to invent the law (retributive justice as outrageous as the offence), she leans forward, distancing herself from staid and stale solutions inapplicable in rapidly evolving situations. Technology goes faster than the law's ability to constrain abuses and Kittleson shows here that the law is also a creative process.

The questions treated are difficult to answer. Becoming aware of issues currently in debate is vital to the construction of a dynamic legal culture and informed, responsible citizenship, itself vital to democracy. The discussions that take place in court or among lawyers in the elevators, in the corridors, the bathroom or at the conference table, are important because they give the public insights they would not necessarily have.

25 «Home Invasions», season 3, episode 20, first aired April 18, 1999 
Another pertinent issue today is the credibility of visual evidence. Courtrooms are nearly all equipped with computer screens, and wall screens on which the parties can show videos or photographs in support of their arguments. Many series today show prosecutors and defense teams making use of visual evidence, even preparing power point presentations. The credibility of anonymously provided videos are the object of a scene in Eli Stone ${ }^{26}$. The prosecutor requests that a video be used to prove the accused had the possibility to commit a particular crime ${ }^{27}$. Opposing counsel move to have the video dismissed as evidence in court. They base their argument on the principle that video is not credible evidence if its origin is unknown because manipulation of visual material is conceivable. They come to the judge's chambers (where discussion of such a motion could actually take place) in presence of the prosecutor (another element of realism) to show a video in support of their argument. The judge, an AsianAmerican woman eating her lunch during the meeting, is convinced by the trick video in which the accused's head is replaced by that of the prosecutor himself. Again reality is played with in this episode, but the question of credibility of visual evidence comes across clearly to the audience.

The scene also demonstrates television's ability to talk about itself and about the act of viewing. Fiske calls this television selfreflexivity ${ }^{28}$. Besides the issue of reliable visual evidence, currently in debate among jurists, it is a reminder to conserve a degree of distance from television content, not to take to the letter everything viewers see there. The public is now capable of entering this debate, especially in the context of digital technology where everyone can engage in virtually professional image-making, taking pictures with high performance telephone cameras, even making films that end up on the Internet. These practices are not new for television, playing with reality in obvious ways, to remind viewers that they are watching television. Producers know they are now dealing with sophisticated audiences; a straight-forward story is just another story.

Law is much more of a creative activity than most people believe. Lawyers must be quick thinkers and talented orators. Playing with representing how to argue opens the imagination to what arguments are possible, inviting viewers into a creative thinking process with respect to the law. The issues are real, courtroom behaviors need no longer be rigidly portrayed. The articulation of the real, fiction and the imagination enhance viewers' comprehension of

\footnotetext{
${ }^{26} \mathrm{ABC}, 2008-2009$.

27 « Praying for Time », season 1, episode 8, first aired March 20, 2008

${ }^{28}$ J. Fiske, Television Culture, London, Routledge, 1987, p. 238.
} 
the legal system and the workings of the law. Awareness of the importance and of the role of the law in every day life, of a citizen's rights and obligations, of the issues courts must deal with, gives audiences criteria to follow discussions on juvenile crime, the international problem of terrorism and the law, on prisons and recidivism, judicial accountability, differences in criminal procedures from one country to another, and so on.

Procedurals today relate the world of the law efficiently because of this mixture of realism with an invitation to put one's imagination into motion. Viewers, who are citizens and potential jurors, must engage in a reflection in order to follow the different aspects of a legal issue and to evaluate court opinions and legislation. A certain degree of realism is helpful to put things in place. Effects must be real or else producers are taking viewers for idiots. The challenge for the imagination need not be to determine what robe a judge wears, nor what seat a witness occupies, nor who can be present at what meeting. The challenge resides in the questions asked and the ways these questions are proposed to the public. Is it not more important to give a real context to invented stories than an approximate framework to real stories? Real stories involve real people, and too much reality can hurt them; notoriety makes it impossible for them to turn the page and begin a new life. A real framework puts the imagination to work in a particular context and feeds the imaginary.

Justice OW Holmes ${ }^{29}$ is known to have said: "Man's mind, once stretched by a new idea, never regains its original dimensions 30 ". This is the project producers of many legal series have undertaken today: to provoke critical and creative thinking among viewers of their programs.

\footnotetext{
29 1841-1935, associate Justice on the US Supreme Court from 1902- 1932.
}

$3^{\circ} \mathrm{http}$ ://www.quotationspage.com/quotes/Oliver Wendell Holmes 